\title{
Counterculture Studies
}

Volume 1 | Issue 1

Article 7

2018

Thoughts on Rolling Stone turning 50 - Men behaving badly, none so much as America's top soldiers

Phillip Frazer

frazer@newslet.com

Follow this and additional works at: https://ro.uow.edu.au/ccs

\section{Recommended Citation}

Frazer, Phillip, Thoughts on Rolling Stone turning 50 - Men behaving badly, none so much as America's top soldiers, Counterculture Studies, 1(1), 2018, 74-79. doi:10.14453/ccs.v1.i1.7 


\title{
Thoughts on Rolling Stone turning 50 - Men behaving badly, none so much as America's top soldiers
}

\author{
Abstract \\ The following reminiscences and commentary by Phillip Frazer, original editor of the Australian edition of \\ Rolling Stone, were first published during April 2017 in the Byron Echo and at dailyreview.com.au. In \\ November of that year Joe Hagan's The Life and Times of Jann Wenner and Rolling Stone Magazine \\ appeared in bookshops around the world. Wenner was the American founder and editor of the magazine. \\ Since it was first published, the uninhibited biography has generated some controversy, initially due to a \\ falling out between the biographer and his subject, but also in connection with the portrait of Wenner \\ revealed therein. For example, one commentator noted upon reading the book: 'All the sex, drugs \& rock ' $n$ ' \\ roll got a bit tiring after a while. Wenner may have been a "clever" businessman (to some extent) and got \\ the right people on side, but despite his friendships with Springsteen and company, he was a rather \\ despicable cad in many ways.' Though Frazer met up with Wenner and had ongoing contact, the \\ Australian edition of Rolling Stone appears to have been left to follow its own path, based around the \\ American magazine's successful template and the experience built up locally through Frazer's experience \\ with pop, rock and counterculture magazines such as GoSet (1965-73), Revolution (1970-1), High Times \\ (1971-2) and The Digger (1972-5).

\section{Creative Commons License} \\ (c) (7)
}

This work is licensed under a Creative Commons Attribution 4.0 License. 


\title{
Thoughts on Rolling Stone turning $\mathbf{5 0}$
}

\section{Men behaving badly, none so much as America's top soldiers}

\author{
Phillip Frazer
}

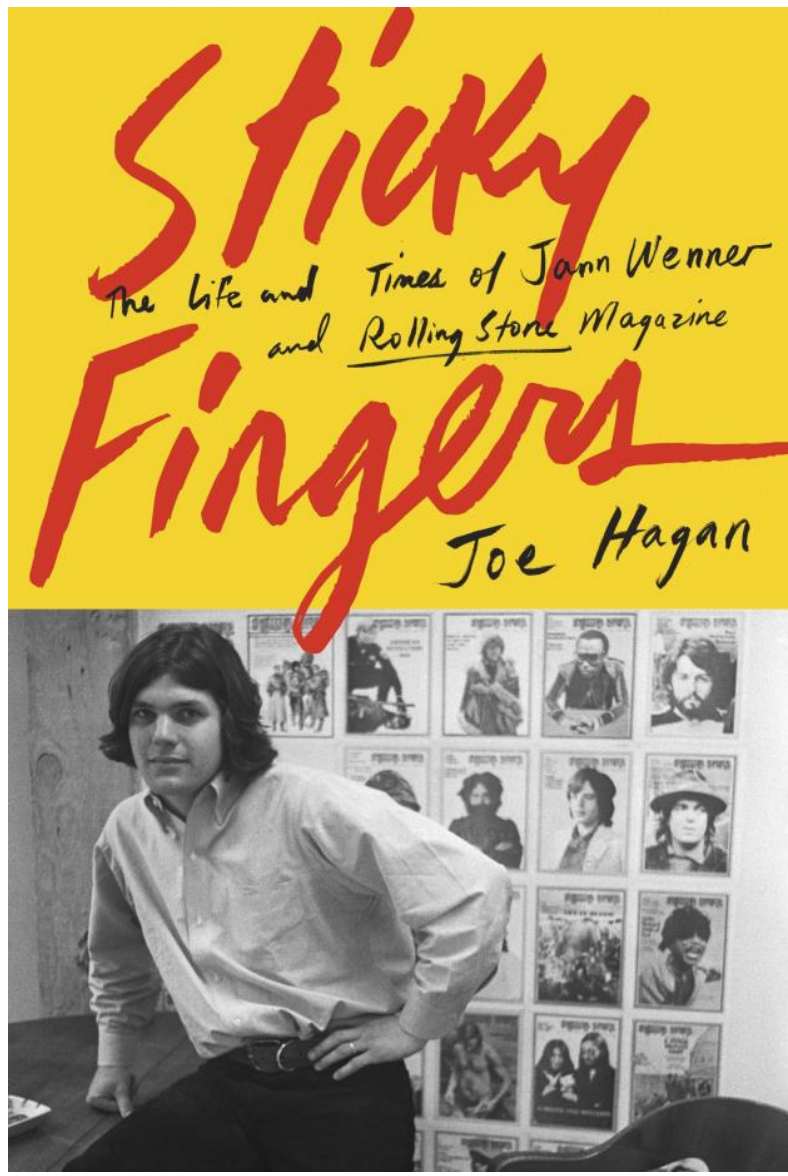

\{The following reminiscences and commentary by Phillip Frazer, original editor of the Australian edition of Rolling Stone, were first published during April 2017 in the Byron Echo and at dailyreview.com.au. In November of that year Joe Hagan's The Life and Times of Jann Wenner and Rolling Stone Magazine appeared in bookshops around the world. Wenner was the American founder and editor of the magazine. 
Since it was first published, the uninhibited biography has generated some controversy, initially due to a falling out between the biographer and his subject, but also in connection with the portrait of Wenner revealed therein. For example, one commentator noted upon reading the book: 'All the sex, drugs \& rock ' $n$ ' roll got a bit tiring after a while. Wenner may have been a "clever" businessman (to some extent) and got the right people on side, but despite his friendships with Springsteen and company, he was a rather despicable cad in many ways.' Though Frazer met up with Wenner and had ongoing contact, the Australian edition of Rolling Stone appears to have been left to follow its own path, based around the American magazine's successful template and the experience built up locally through Frazer's experience with pop, rock and counterculture magazines such as GoSet (1965-73), Revolution (1970-1), High Times (1971-2) and The Digger (1972-5).\}

This year [2017], Rolling Stone magazine is celebrating its 50th year on American newsstands. It's also 45 years since I launched the Australian edition, which is still going strong. Back in 1967, I was doing politics at Monash University and publishing a pop-music tabloid called GoSet, selling 70,000 copies a week across Australia. America had no nationwide music paper until late that year when a university dropout named Jann Wenner started Rolling Stone. Jann and his writers, designers, and photographers believed that, more than fun dancing-music, rock ' $n$ ' roll was an expression of an emerging youth culture that would change the world. I shared that sense, though my parents were serious (but critical) lefties, so I was brought up to be skeptical of social change unless it involved redistributing economic power.

In 1970, I stayed for two weeks with Jann and his wife Janie in San Francisco, and apart from having fun we made a deal that I would publish an Australian edition of his culture-challenging fortnightly, launching in January 1972. 


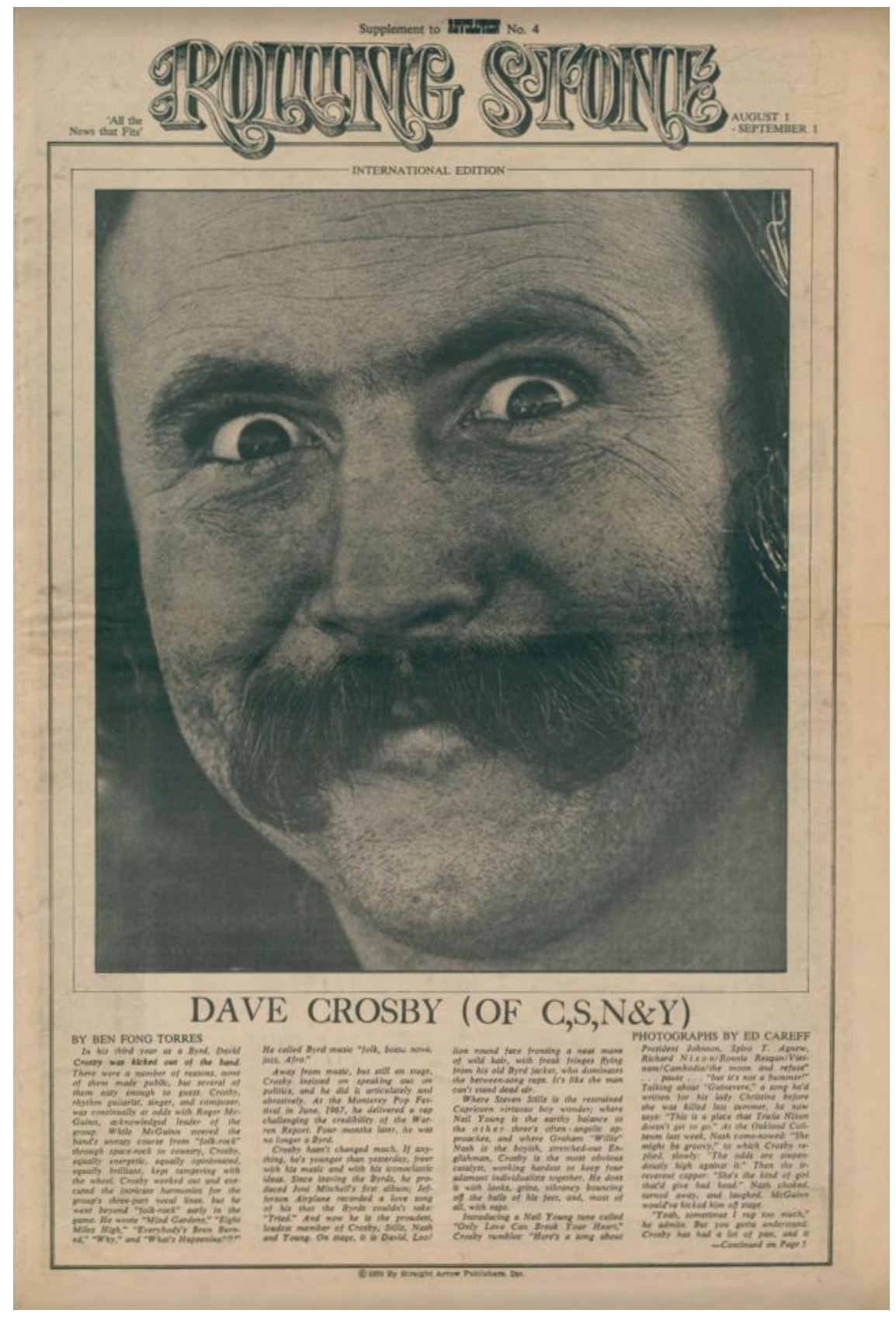

First page of the Rolling Stone Australian supplement in Phillip Frazer's Revolution magazine, August 1970

Working out of a group house in Glebe, a few mates and I coaxed the Aussie Stone toward sustainability. Then, in 1976, I sold the Australian franchise to a trio of Sydney gonzo publishers and moved myself to New York. My interests were in political, environmental, and cultural upheaval, all of which I was in favour of, so I kept up with Rolling Stone during my New York decades through 
occasional encounters with Wenner and by reading the infrequent outside-the-box political stories he published.

On this $50^{\text {th }}$ anniversary of Rolling Stone, these few major stories from the archives stay with me:

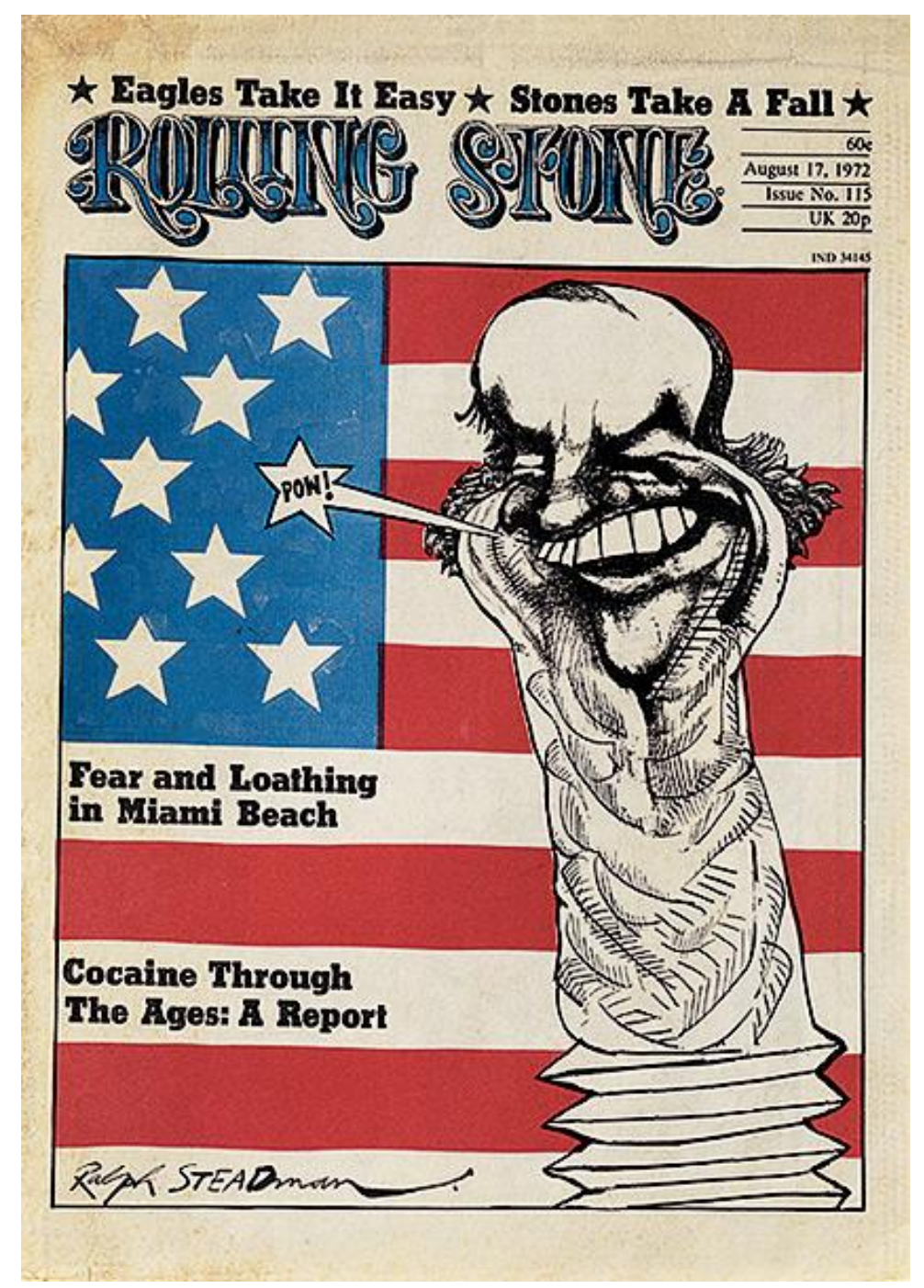

August 1972 Australian edition of Rolling Stone, featured Hunter S. Thompson's take on Democratic

Party presidential candidate Sen. George McGovern

Tom Wolfe's radical chic. When I arrived at the Wenners' home in 1970, that night's real dinner guest was Tom Wolfe, the writer of four books with long titles such as The Electric Kool-Aid Acid Test. Jann and Tom talked about The Brotherhood of the Right Stuff, a story about American astronauts that 
Tom was writing for an upcoming issue of Stone, with photos by Annie Leibovitz on the biggest assignment of her nascent career. Wolfe's stories, dubbed "New Journalism", were rich in lively descriptions of characters, places, and cultures in motion, and major critics of media and literature loved that he inhabited the tripping brains of the heroes while containing them in a well-woven story. Given where we are now in terms of fact/fiction/faction, Tom might have been a mixed blessing to journalism. I also note this quote from Tom: "I think every living moment of a human being's life, unless the person is starving or in immediate danger of death in some other way, is controlled by a concern for status." I don't think that's true.

Fear and Loathing. When we launched the Aussie Stone, Hunter S. Thompson, the chain-babbling trasher of all cultures, was cranking writing genre-bending up a notch with his epic reports on the 1972 US election and on convention events in Las Vegas. HST and his Samoan attorney (actually Mexican) famously travelled with suitcases of booze, pills and white powders, while attempting to unravel white racism toward Latinos. Thompson did a great job of trashing the suit-wearing, overeating, know-nothing guys who run much of America, but his ferociously first-person reportage also may have inspired a million online ratbags.

The reporter who died after killing the General's career. In 2010 Michael Hastings, a 30-year-old freelance writer, spent time on the road with General Stanley McChrystal whom President Obama had put in charge of the US war against the Taliban in Afghanistan. McChrystal and his support crew let Hastings into diplomatic meetings, late-night booze-ups, and heavily armed visits to alienated Afghanis and disillusioned GIs. Hastings' story for Rolling Stone faithfully reproduced the General's no-bullshit repartee, making it stunningly clear that McChrystal and his fellow top brass were appallingly full of shit -- also ignorant, arrogant, crazy violent, and destined to fail at saving Afghanistan. After Obama read the article, he fired McChrystal and backed away from his "strategy" 
of having troops occupy villages to hunt down insurgents while simultaneously uplifting the good citizens. US military and intelligence honchos don't like being discredited by journalists (or black Harvard-educated Presidents), and they may have had a role in Hasting's violent death in June 2013. In March 2017 WikiLeaks released documents on how the CIA can remotely control recent model cars. Hastings' Mercedes hit a pole at full speed on a suburban street in LA at 4:25am.

Yes there is a theme in all this - it's all about men behaving badly, sometimes the writers themselves. Jann always tilted his magazine strongly toward men as contributors, and readers ( $66 \%$ male). In a list of "50 notable current and former staff of Rolling Stone" on Wikipedia, there are only three women. One is a music journalist, one was publisher for seven years and is not well-remembered by the company, and the third is Sabrina Erdely, who wrote the notorious Stone investigative piece titled A Rape on Campus in 2014 which was subsequently adjudged profoundly flawed, costing Wenner Media millions of dollars in multiple defamation and libel cases (still ongoing).

I put Hastings' revelations about just how crass and dangerous the Masters of War really are, at the top of Rolling Stone's journalistic achievements. Me, I'm a little bit glad Wenner has published Stone for all those years -- and glad I didn't.

Footnote: Jeune Pritchard interviews Phillip on ABCTV in January 1972, about the showdown with Rupert Murdoch's Southdown Press over the launch of the Australian Stone -- here: http://www.youtube.com/watch?v=3UBNHDxB9ZM

Phillip Frazer blogs at coorabellridge.com 